\title{
Evaluation of Yield Potential and Dry Matter Content of Promising Clones of Orange Fleshed Sweetpotato Rich in Betacarotene
}

\author{
Febria Cahya Indriani ${ }^{*}$, Joko Restuono ${ }^{1}$, Wiwit Rahajeng ${ }^{1}$, Yuliantoro Baliadi ${ }^{1}$, Made \\ Jana Mejaya ${ }^{1}$
}

Indonesian Legumes and Tuber Crops Research Institute (ILETRI) East Java, Indonesia

\begin{abstract}
Public awareness of foods that have physiological functions for health is increasing. Consumption of orange fleshed sweetpotato not only meets carbohydrate requirements but also beta-carotene which is good for eye health. The aim of this reserach was to evaluate the yield potential and levels of dry matter content of promising clones of orange fleshed sweetpotato rich in beta-carotene. The study was conducted in Malang, East Java in Dry Season II 2016. Genetic materials used were 20 sweetpotato clones, including Beta-1 and Beta-2 varieties as a check. The treatment design used a randomized block design with three replications. The results showed that the clones tested had a potential yield ranging from $20.9-35.1 \mathrm{t} / \mathrm{ha}$ with an average of $25.2 \mathrm{t} / \mathrm{ha}$. There were three clones had a higher yield potential than the check varieties Beta-1 and Beta-2. Dry matter content ranged from $17.0-31.6 \%$ with an average of $25.7 \%$. Fifteen clones had higher levels of dry matter content than check varieties Beta-1 and Beta-2. MSU 14018-06, MSU 14001-20 and MSU 14027-02 clones had high yield potential and dry matter content. All three clones have the opportunity to be released as new superior varieties of orange fleshed sweet potato rich in beta-carotene.
\end{abstract}

Keywords: orange flesh sweetpotato, betacaroten, dry matter content, yield potential.

*Corresponding Author:

E-mail: febria_cahya@yahoo.co.id (Febria Cahya Indriani)

Indonesian Legumes and Tuber Crops Research Institute (ILETRI) East Java, Indonesia

\section{INTRODUCTION}

Food diversification launched by the Indonesian government encourages consumption of other carbohydrate sources besides rice in meeting basic needs. This is intended to change people's consumption patterns to be more varied in food consumption and to increase nutritional value (Lastinawati 2010). Sweet potato is one of the commodities that is widely used as an alternative food source. In addition to carbohydrate sources, this commodity is rich in nutrients. Orange flesh sweetpotato contains beta-carotene which functions as provitamin $\mathrm{A}$, which can be converted into vitamin A. Vitamin A is useful for eye health as well as provides protection against cancer, premature aging, decreased immunity of heart disease, stroke, cataracts and muscular disorders due to its ability as an antioxidant to ward off free radicals (Widowati 2010).

Besides the above issues, stunting (baby grows short or dwarf) issue is still a problem in several regions in Indonesia. The growth and development of the human body is also influenced by Vitamin A which is an important nutrient needed by the human body (Kapil \& Sachdev 2013). Vitamin A is not produced by the body but from daily food, so consumption of commodities rich in vitamin A is very necessary. According to Bloem et al. (2013) stunting is a form of growth failure due to accumulation of nutrient 
insufficiency that lasts long from pregnancy to 24 months of age. Nutrition problem is still a major problem in developing countries including Indonesia. Therefore, efforts are needed to prevent and reduce the impact due to the lack of nutrition of the community. The role of food commodities with high nutritional content is needed for healthy food alternatives. For example the role of OFSP (orange flesh sweetpotato) varieties specifically developed in Eastern Africa in a strategic effort to overcome vitamin A deficiency (Tumwegamire et al. 2011).

Sweetpotato demand prediction in the 2016-2020 period for direct consumption or consumption of sweetpotato at the household level is expected to increase with growth of $4.55 \%$ per year, so it needs to be balanced with increased production (Kementan 2016). Efforts to increase sweet potato production can be done through the use of superior varieties, improved management of sweet potato farming with the use of balanced fertilizers (Sasongko 2009). Utilization of superior varieties of sweetpotatoes that contain high nutrition, high yield potential and wide adaptation is needed to increase sweet potato production in Indonesia in addition to expanding the planting area. The socialization of the orange sweet potato commodity needs to be carried out by all parties, not only the role of the government but also the private sector and all Indonesian people. The industrial sector can produce and market nutritious processed products from sweet potatoes. Meanwhile the government can support by setting standards, promoting healthy and nutritious food and ensuring access to nutritious food for areas that are in need (Bloem 213). The involvement of various sectors such as government, private and civil society will be easy to realize the increase improvement of community nutrition (Mitra, 2015).

The development program for superior varieties of sweetpotato in Indonesia continues to be carried out mainly for food and industrial purposes. For the purpose of food, the formation of superior varieties of orange sweetpotato is directed to produce varieties with high dry matter and high beta-carotene content in addition to high yield potential. Orange sweetpotato is also likely to be used as a natural food coloring (Ginting 2013). By consuming orange sweetpotato, not only carbohydrate needs are met, but also vitamin A needs are also fulfilled. Plant breeding programs continue to be carried out to get new clones that are better than existing superior varieties. Improvement of tuber shape character, increased levels of dry matter, tolerance to biotic and abiotic stresses and its adaptability to the growing environment are still very much needed. A wide selection of sweetpotato varieties with various advantages possessed is expected to increase the interest of farmers to plant orange sweetpotato which is supported by favorable prices, increasing added value and competitiveness. It is expected that orange sweetpotato rich in beta-carotene is expected to play a role in overcoming the problem of malnutrition that has plagued several places in Indonesia. The aim of this reserach was to evaluate the yield potential and levels of dry matter content of promising clones of orange fleshed sweetpotato rich in betacarotene.

\section{METHODS}

The study was conducted in Malang in Dry Season (DS) II 2016 using a randomized block design (RBD) with three
Journal Homepage:

http://ejournal.undwi.ac.id/index.php/jsds
Copyright (C) 2020 Dwijendra University. All right reserved. 
replications. The research material was 20 clones including two check varieties of Beta-1 and Beta-2. Each clone was planted in a plot of $3 \mathrm{~m} \times 5 \mathrm{~m}$ with plant spacing of $100 \mathrm{~cm} \times 25 \mathrm{~cm}$. Fertilization uses a dose of $300 \mathrm{~kg}$ Phonska compound fertilizer and manure $2 \mathrm{t} / \mathrm{ha}$. Phonska fertilizer was given 2 times, namely when the plant was one week old with a dose of one-third part of the fertilizer and the rest was given at the age of 1.5 months after planting, while manure was only at planting time.

Weeding was done depending on the growth of weeds, namely at the age of 4,7 and 10 weeks after planting. Declining of mound was done when the plant was one month old along with the first weeding. Reversal of the stems was carried out when the plants were 6,9 , and 12 weeks after planting while lifting the mound was done at 2 months after planting together with the second weeding and supplementary fertilizers. Irrigation was done as needed to prevent drought or lack of water. Prevention of weevil pest (Cylas formicarius) and scab disease (Sphaceloma batatas) attacks was done by giving furadan $3 \mathrm{G}$ with a dose of $17 \mathrm{~kg} / \mathrm{ha}$ by kerf, and Furadan was repeated during the sweet potato tuber enlargement phase (2 months old). Before planting, cuttings were soaked in a mixture of larvin solution and Dithane M45 (1-2 cc / liter of water) for 5 minutes. Pest control or other diseases were carried out intensively and harvesting was done at the age of 4.5 months after planting.

Observations included the agonomy characters, such as: tuber production ( $\mathrm{t} / \mathrm{ha})$, tuber dry matter and tuber dry matter production ( $\mathrm{t} / \mathrm{ha}$ ). While the morphological characters observed included skin color and tuber flesh, beta carotene level (visually), tuber shape score, uniformity of shape and size of tubers, cracking, weevil pest attack on tubers.

\section{RESULT AND DISCUSION}

\section{Yield Potential}

Results of this research showed that there were differences in the evaluated clones against the potential variables of fresh tuber yield, dry matter and dry matter production (Table 1). Yield potential of sweet potato clones ranged from 20.2 $35.1 \mathrm{t} / \mathrm{ha}$. The three clones that had high average yield potential were MSU 1400120, MSU 14018-06, and MSU 14027-02, with yield potential of $\geq 30 \mathrm{t} / \mathrm{ha}$. Three orange sweet potato clones with high yield potential ( $\geq 30 \mathrm{t} / \mathrm{ha}$ ) were selected and will be used to improve the existing superior varieties.

TABLE 1.

Yield potential of fresh tubers, dry matter content and dry mater production of orange sweet potato promising clones Malang, DS II 2016.

\begin{tabular}{|c|c|c|c|c|}
\hline No. & Clones Name & $\begin{array}{l}\text { Yield potential } \\
(\mathbf{t} / \mathrm{ha})\end{array}$ & $\begin{array}{c}\text { Dry } \\
\text { matter } \\
(\%)\end{array}$ & $\begin{array}{c}\text { Dry matter } \\
\text { production } \quad(t / h a)\end{array}$ \\
\hline 2. & MSU 14017-01 & $22.1 \mathrm{gh}$ & $24.6 \quad b-f$ & $5.4 \mathrm{f}-\mathrm{h}$ \\
\hline 3. & MSU 14018-06 & $31.0 \mathrm{ab}$ & 25.5 b-e & 7.8 a-d \\
\hline 4. & MSU 14018-07 & 22.8 f-h & $24.8 \quad b-e$ & 5.7 e-h \\
\hline 5. & MSU 14027-04 & $21.9 \mathrm{gh}$ & $29.9 \mathrm{ab}$ & $6.5 \quad \mathrm{c}-\mathrm{g}$ \\
\hline 6. & MSU 14012-02 & $20.9 \mathrm{~h}$ & 28.9 a-c & 6.0 d-h \\
\hline 7. & MSU 14002-80 & $21.9 \mathrm{gh}$ & $29.6 \quad a-c$ & $6.5 \quad c-g$ \\
\hline 8. & MSU 14028-01 & $26.4 \quad c-g$ & $28.4 \quad \mathrm{a}-\mathrm{c}$ & $7.5 \quad b-e$ \\
\hline 9. & MSU 14012-05 & 22.9 f-h & $25.0 \quad$ b-e & 5.7 e-h \\
\hline
\end{tabular}

Journal Homepage:

http://ejournal.undwi.ac.id/index.php/jsds
Copyright @ 2020 Dwijendra University. All right reserved. 
Journal of Sustainable Develpment Science

Vol. 2, No. 2, December 2020, pp. 60-68

e-ISSN: 2715-9140 | p-ISSN: 2722-919X

\begin{tabular}{|c|c|c|c|c|}
\hline 10. & MSU 14024-07 & $21.0 \mathrm{~h}$ & $27.7 \quad a-c$ & $5.8 \mathrm{~d}-\mathrm{h}$ \\
\hline 11. & MSU 14001-20 & $35.1 \mathrm{a}$ & 27.8 a-c & $9.7 \mathrm{a}$ \\
\hline 12. & MSU 14028-04 & $20.2 \mathrm{~h}$ & $28.6 \quad a-c$ & 5.8 e-h \\
\hline 13. & MSU 14020-07 & $21.2 \mathrm{~h}$ & $24.6 \quad b-f$ & $5.2 \mathrm{gh}$ \\
\hline 14. & MSU 14027-02 & $30.7 \quad a-c$ & $27.0 \quad$ a-e & 8.3 a-c \\
\hline 15. & Beta 2 & $29.6 \quad b-d$ & $23.7 \quad c-f$ & $6.4 \quad c-g$ \\
\hline 16. & Beta 1 & $22.4 \mathrm{gh}$ & 21.6 d-g & $5.3 \mathrm{f}-\mathrm{h}$ \\
\hline 17. & MSU 14014-84 & 25.9 d-g & 27.6 a-d & 7.2 b-f \\
\hline 18. & MSU 14015-01 & $27.1 \quad b-f$ & $31.6 \quad \mathrm{a}$ & 8.6 a-b \\
\hline 19. & MSU 14020-08 & 24.7 e-h & $17.0 \mathrm{~g}$ & $\begin{array}{ll}4.3 & \mathrm{~h} \\
\end{array}$ \\
\hline \multirow[t]{4}{*}{20.} & MSU 14027-01 & $28.6 \quad$ b-e & $18.6 \mathrm{fg}$ & $5.3 \mathrm{f}-\mathrm{h}$ \\
\hline & Average & 25.23 & 25.70 & 6.45 \\
\hline & $\mathrm{CV}(\%)$ & 11.04 & 14.31 & 18.55 \\
\hline & $\operatorname{LSD}(\%)$ & 4.60 & 6.08 & 1.97 \\
\hline
\end{tabular}

Production of orange flesh sweetpotato and dried tuber material is a selection criterion as an indicator of the level of clone adaptation to certain environmental conditions (Mekonnen et al. 2015). The number of tubers, tuber weights and tuber yields had high broad significance heritability values and high genetic progress promising. These characters are useful as a basis for selection and have the potential to provide a positive response in efforts to improve the tuber yield of sweet potatoes (Rahajeng and Rahayuningsih 2015). The adaptability of the promising clones to the existing environmental conditions is also needed so that it is expected that in the future the varieties will be obtained that are able to adapt in various environments. Environmental factors and genotypes greatly affect sweetpotato production (Kathabwalika et al. 2013). It also greatly determines the growth and stability of the yields of sweetpotato clones evaluated (Mau et al. 2013). Saitama et al. (2017) which states the response of ten superior varieties of sweet potatoes in the dry and rainy season show a difference, some varieties show a high effect on the environment as indicated by vegetative growth and yields.

\section{Dry Matter Content}

Dry matter content is one of the selection criteria because it can be used as an indicator of tuber quality. The dry matter content of the clone tubers tested varied with a range of $17.03-31.63 \%$ and an average of $25.70 \%$ (Table 1). Three clones MSU 14015-01, MSU 14027-04 and MSU 14002-80 had high levels of dry matter, namely $31.6,29.9$, and $29.6 \%$, respectively. Whereas the check varieties of Beta 1 and Beta 2 had tubers dry matter content of 21.6 and $23.7 \%$, respectively. Orange sweet potato generally has a dry matter content $<30 \%$ (tends to be low), which is caused by a positive correlation of beta-carotene content with tuber water content, whereas water content is negatively correlated with the dry matter tuber content (Indriani et al. 2016). This indicates that clones with low dry matter will contain high water content. High levels of dry matter are needed if sweet potatoes will be used as raw material for flour and starch to get high yields (Ginting et al. 2012).

\section{Dry Matter Production}

Dry matter production in sweetpotato plants depends on the availability of solar radiation, the photosynthetic capacity of the plant and the duration of that capacity. Increased radiation or photosynthetic activity and 
maintenance over a long period of time will increase the production of dry matter (Kuo and Chen, 1992). Average dry matter production of tubers was in the range of $4.3-9.6 \mathrm{t} / \mathrm{ha}$ with an average of $6.5 \mathrm{t} / \mathrm{ha}$. There were three clones had an average dry matter production of $>7.0 \mathrm{t} / \mathrm{ha}$. The three clones MSU 14001-20, MSU 1401501, and MSU 14027-02 had an average dry matter tubers production of 9.6, 8.6, and $8.2 \mathrm{t} / \mathrm{ha}$, respectively. Whereas the average production of the two checkn varieties, Beta 1 and Beta 2, were 5.3 and $6.4 \mathrm{t} / \mathrm{ha}$, respectively. This show the opportunity to obtain better promising clones from existing superior varieties.

\section{Tuber Performance}

Tuber performance includes tuber shape (good or not good), tuber quality, uniformity of shape and size, surface smoothness (tuber defects and tuber crunching). Twenty clones of orange sweet potato tested had a tuber shape score of 3.3 (quite good). Meanwhile, Beta 1 and Beta 2 varieties had a score of 3.0 and 4.0, respectively. The shape of the tubers is very important if used for consumption, a good tuber shape will be more attractive, in addition to the smooth surface of the tuber. Whereas for tuber quality, in general the score were 3.0 and 4.0 , this indicated that most of them have moderate and rather good quality. There was one clone that had a score of 5.0 which showed good tuber quality, namely MSU 14001-20 clone. Other selection parameters observed were uniformity of the shape and size of the tuber. Farmers or consumers generally prefer uniform tubers both in terms of shape and size. The clones and varieties tested had uniformity of form with an average score of 3.9 with interval scores 3.0 - 5.0. MSU 14028-01 clone had a tuber shape uniformity score of 5.0 (uniform) which means it was in the uniform category and the uniformity of the size of the clones belongs to the rather uniform category. This showed that most of these clones had the prospect of being released as new superior varieties of orange sweet potato with high yield potential and dry ingredients.

Tuber crispness is also a selection parameter on sweet potato. Crispy sweet potato causes the appearance of the tuber is not good so the price is also lower. Cracks can be caused by nematodes, genetic or too long harvest periods. Usually the early maturing clones or varieties when harvested too long will become crunchy so that their appearance is less attractive. Crispy tuber clones of orange sweet potato clones had an average score of 4.0, which means that the cracks in tubers range between $11-25 \%$. There were 7 promising clones that had a score of 5.0 (no crack on tubers). This shows that the seven clones have the opportunity to be selected as hope clones, while the check varieties Beta 1 and Beta 2 each had a score of 3.0 (having tuber crunches between 26-50\%) as shown in Table 2.

TABLE 2.

Tuber shape, quality, uniformity and crunching of tubers in orange sweet potato promising clone having high beta carotene. Malang DS II 2016.

\begin{tabular}{|c|c|c|c|c|c|c|}
\hline \multirow{2}{*}{ No. } & \multirow{2}{*}{$\begin{array}{c}\text { Clones/ } \\
\text { Varieties }\end{array}$} & & & \multicolumn{2}{|c|}{ Tuber homogenety } & \multirow{2}{*}{ Cracks $^{\text {c) }}$} \\
\cline { 1 - 3 } & Tuber shape & Tuber quality & S) & Shape & Size & \\
\hline 1 & MSU 14011-09 & 4.0 & 4.0 & 4.0 & 4.0 & 4.0 \\
\hline
\end{tabular}

Journal Homepage:

http://ejournal.undwi.ac.id/index.php/jsds
Copyright (C) 2020 Dwijendra University. All right reserved. 
Journal of Sustainable Develpment Science

Vol. 2, No. 2, December 2020, pp. 60-68

e-ISSN: 2715-9140 | p-ISSN: 2722-919X

\begin{tabular}{|c|l|l|l|l|l|l|}
\hline 2 & MSU 14017-01 & 3.0 & 3.0 & 3.0 & 3.0 & 4.0 \\
\hline 3 & MSU 14018-06 & 4.0 & 2.0 & 4.0 & 4.0 & 4.0 \\
\hline 4 & MSU 14018-07 & 3.0 & 2.0 & 4.0 & 3.0 & 3.0 \\
\hline 5 & MSU 14027-04 & 4.0 & 4.0 & 4.0 & 3.0 & 4.0 \\
\hline 6 & MSU 14012-02 & 3.0 & 4.0 & 4.0 & 4.0 & 3.0 \\
\hline 7 & MSU 14002-80 & 3.0 & 4.0 & 4.0 & 3.0 & 3.0 \\
\hline 8 & MSU 14028-01 & 4.0 & 4.0 & 5.0 & 4.0 & 4.0 \\
\hline 9 & MSU 14012-05 & 4.0 & 4.0 & 4.0 & 4.0 & 5.0 \\
\hline 10 & MSU 14024-07 & 3.0 & 4.0 & 4.0 & 3.0 & 4.0 \\
\hline 11 & MSU 14001-20 & 4.0 & 5.0 & 4.0 & 4.0 & 5.0 \\
\hline 12 & MSU 14028-04 & 3.0 & 4.0 & 4.0 & 4.0 & 3.0 \\
\hline 13 & MSU 14020-07 & 2.0 & 3.0 & 4.0 & 3.0 & 3.0 \\
\hline 14 & MSU 14027-02 & 3.0 & 3.0 & 4.0 & 4.0 & 5.0 \\
\hline 15 & Beta 2 & 4.0 & 4.0 & 4.0 & 4.0 & 3.0 \\
\hline 16 & Beta 1 & 3.0 & 3.0 & 3.0 & 2.0 & 3.0 \\
\hline 17 & MSU 14014-84 & 4.0 & 2.0 & 4.0 & 4.0 & 5.0 \\
\hline 18 & MSU 14015-01 & 2.0 & 3.0 & 4.0 & 4.0 & 5.0 \\
\hline 19 & MSU 14020-08 & 3.0 & 3.0 & 4.0 & 3.0 & 5.0 \\
\hline 20 & MSU 14027-01 & 3.0 & 3.0 & 3.0 & 3.0 & 5.0 \\
\hline & Average & $\mathbf{3 . 3}$ & $\mathbf{3 . 4}$ & $\mathbf{3 . 9}$ & $\mathbf{3 . 5}$ & $\mathbf{4 . 0}$ \\
\hline
\end{tabular}

Note:

a) $5=$ very good, $4=$ good, $3=$ moderately good, $2=$ bad, $1=$ very bad.

b) $5=$ very homogen, $4=$ homogen, $3=$ moderately homogen, $2=$ not homogen, $1=$ least homogen

c) $1=>75 \%$ cracks, $2=51-75 \%$ cracks, $3=26-50 \%$ cracks , $4=11-25 \%$ cracks and 5 $=$ no cracks.

d) $1=$ attack $>75 \%, 2=$ attack $51-75 \%, 3=$ attack $26.50 \%, 4=$ attack $11-25 \%, 5=$ attack 0-10\% (Rasco 1994).

\section{Skin Color and Tuber Flesh}

The tubers color of the orange sweetpotato clones was generally red with varying degrees of color brightness. The superior varieties of orange flesh sweetpotato Beta-1 and Beta-2 had dark red skin color (score 6.0). MSU 14027-04 clone was the only clone that had light yellow skin color (Table 3). The color of tuber flesh is generally orange which indicates beta carotene content, visually high levels of beta-carotene can be seen from the darker orange color. From 20 clones / varieties studied, there were 3 clones which had orange flesh color with yellow combination, the three clones were MSU 14027-04, MSU 14018-07 and MSU 14012-02. The expectation clones of MSU 14024-07, MSU 14001-20, MSU 1402804, MSU 14020-07 and MSU 14027-02 respectively showed slightly darker orange tuber (O5) color, while 3 clones gave orange orange flesh color. The dark (O6) of the three clones are MSU 14011-09, MSU 14002-80 and MSU 14020-08. The tuber flesh in the Beta-2 comparison variety has a score of 3 and Beta- 1 has a
Journal Homepage:

http://ejournal.undwi.ac.id/index.php/jsds
Copyright (C) 2020 Dwijendra University. All right reserved. 
very dark orange flesh $(\mathrm{O} 7)$ color as shown $\quad$ in Table 3.

TABLE 3.

Skin color and tuber flesh of the orange sweetpotato clones. Malang DS II 2016.

\begin{tabular}{|l|l|l|l|l|l|}
\hline \multirow{2}{*}{$\begin{array}{l}\text { Clones name/ } \\
\text { Varieties }\end{array}$} & \multicolumn{2}{|c|}{ Tuber color } & $\begin{array}{l}\text { Clones name/ } \\
\text { Varieties }\end{array}$ & \multicolumn{2}{c|}{ Tuber color } \\
\cline { 2 - 6 } & skin $^{\text {a) }}$ & flesh $^{\text {b) }}$ & & skin $^{\text {a) }}$ & flesh $^{\text {b) }}$ \\
\hline MSU 14011-09 & R6 & O6 & MSU 14001-20 & R6 & O5 \\
\hline MSU 14017-01 & R3 & O4 & MSU 14028-04 & R3 & O5 \\
\hline MSU 14018-06 & R3 & O4 & MSU 14020-07 & R1 & O5 \\
\hline MSU 14018-07 & R5 & Y3O2 & MSU 14027-02 & R3 & O5 \\
\hline MSU 14027-04 & Y3 & Y3O1 & Beta-2 & R6 & O3 \\
\hline MSU 14012-02 & R6 & Y3O3 & Beta-1 & R6 & O7 \\
\hline MSU 14002-80 & R6 & O6 & MSU 14014-84 & R4 & O4 \\
\hline MSU 14028-01 & R3 & O3 & MSU 14015-01 & R3 & O3 \\
\hline MSU 14012-05 & R5 & O4 & MSU 14020-08 & R4 & O6 \\
\hline MSU 14024-07 & R6 & O5 & MSU 14027-01 & R3 & O3 \\
\hline
\end{tabular}

Note:

a) tuber skin color: $\mathrm{R}=\mathrm{Red}, \mathrm{Y}=$ yellow, $\mathrm{P}=$ purple, $\mathrm{O}=$ orange, $\mathrm{W}=$ white.

b) flesh color: $1=$ very pale, $2=$ slightly pale, $3=$ pale, $4=$ bright, $5==$ rather dark, $6=$ dark, 7 = very dark $($ Rasco, 1994).

Beta 1 variety had a dark orange flesh color which indicated high levels of beta carotene, however the variety had the shape and size of tubers that were not uniform and the irregular shape of the tubers, that caused obstacles in processing. Therefore in this research it is expected to obtain new sweet potato clones which are rich in beta carotene and have a high dry matter as well and have a good and uniform shape and size of the tubers. The identification of sweetpotato morphology can be used as a basis for the genetic relationship between sweetpotato clones (Warhamni, 2013). The results of the quantification of beta-carotene on 50 accessions of sweetpotatoes showed that most of the clones that had very dark orange tuber flesh color contained betacarotene higher than yellow or orange sweetpotatoes with lighter intensity (Jusuf et al. 2012).

\section{CONCLUSIONS}

There were three clones had the potential yield and dry matter of tubers exceeding the check varieties. The three clones MSU 14001-20, MSU 14018-06 and MSU 14027-02, had a yield potential of 35.1, 31.0, and $30.7 \mathrm{t} / \mathrm{ha}$, respectively and tuber dry matter 27.8, 25.5, and $27.0 \%$, respectively. While the check varieties of Beta 1 and Beta 2 had the potential yield of 22.4 and $29.6 \mathrm{t} / \mathrm{ha}$, respectively with dry matter tubers $21.6 \%$ and $23.7 \%$, respectively.

\section{REFERENCES}

Bloem M.W, S.D.Pee, L.T.Hop, N.C. Khan, A. Laillou, Minarto, R.M.Pfanner, D.Soekarjo, Soekirman, J.A.Solon, C.Theary,E.Wasantwisut. 2013. Key strategies to futhher reduce stunting in Southeast Asia:Lessons from the ASEAN countries workshop.Food and Nutrition Bulletin: 34:2.
Journal Homepage:

http://ejournal.undwi.ac.id/index.php/jsds
Copyright (C) 2020 Dwijendra University. All right reserved. 
Ginting, E., 2013. Carotenoid extraction of orange-fleshed sweetpotato and its application as natural food colorant. J.Teknol dan Industri Pangan. 24 (1): $81-88$.

Ginting, E., 2012. Identifikasi sifat fisik, kimia dan sensoris klon-klon harapan ubi jalar kaya beta karoten. hlm. 612 623. Dalam A.A. Rahmianna, E. Yusnawan, A.Taufiq, Sholihin, Suharsono, T.Sundari dan Hermanto. (Eds). Prosiding Seminar Hasil Penelitian Tanaman Aneka Kacang dan Umbi, 5 Juli 2012. Pusat Penelitian dan Pengembangan Tanaman Pangan, Bogor.

Jusuf, M. I. Hanarida., Minantyorini., T.S.Wahyuni., St.A.Rahayuningsih dan Tjintokohadi. 2012. Konservasi Plasma Nutfah. Dalam. Ubi jalar (Inovasi teknologi dan prospek pengembangan). Pusat Penelitian dan Pengembangan Tanaman Pangan. Bogor.

Indriani, F.C., M. Jusuf. S.Ashari., N. Basuki., dan J. Restuono. 2016. Karakteristik plasma nutfah ubi jalar berdasarkan kandungan bahan kering dan karakter morfologi umbi. hlm. 530 - 539 . Dalam A.A. Rahmianna, D. Harnowo, Sholihin, N.Nugrahaeni, A.Taufiq, Suharsono, E.Yusnawan, E. Ginting, F. Rozi, Hermanto (Eds). Prosiding Seminar Hasil Penelitian Tanaman Aneka Kacang dan Umbi, 25 Mei 2016. Pusat Penelitian dan Pengembangan Tanaman Pangan, Bogor.

Kapil U,H.P.S. Sachdev.2013. Massive dose vitamin A programme in India-Need for a targeted approach: Indian Journal Medical Research. 138 : 411-417.

Kathabwalika, D.M., E.H.C. Chilembwe, V.M. Mwale, D. Kambwa, J.P.Njoloma. 2013. Plant growth and yield stability of orange fleshed sweetpotato (Ipomoea batatas) genotypes in three agro-ecological zones of Malawi. Int.Res.J.Agric.Sci.Soil Sci. 3(11): $383-392$.

Lastinawati, E. 2010. Diversifikasi pangan dalam mencapai ketahanan pangan. AgronobiS 2(4): 11 - 19 .
Mau, Y.S., A.S.S. Ndiwa., I.G.B.A. Arsa., S.S.Oematan. 2013. Agrivita. 35(1): $95-103$.

Mekonnen, B., S. Tulu., J.Nego. 2015. Orange fleshed sweetpotato (Ipomoea batatas L.) varieties evaluated with respect to growth parameters at Jimma in Southwestern Ethiopia. Journal of Agronomy 14(3): $164-169$.

Mitra. 2015.Permasalahan anak pendek (stunting) dan intervensi untuk mencegah terjadinya stunting (Suatu kajiankepustakaan). Jurnal Kesehatan Komunitas. 2(6): $254-261$.

Rahajeng, W dan St. A. Rahayuningsih. 2015. Potensi genetik klon-klon ubi jalar berdasarkan karakter agronomi. hlm. 588 - 595. Dalam A.A.Rahmianna, Sholihin, N. Nugrahaeni, A.Taufiq, Suharsono, N.Saleh, E.Ginting, F.Rozi, I.K. Tastra, Hermanto, E. Yusnawan dan D. Harnowo. (Eds). Prosiding Seminar Nasional Hasil Penelitian Tanaman Aneka Kacang dan Umbi, 19 Mei 2015. Pusat Penelitian dan Pengembangan Tanaman Pangan, Bogor.

Rasco, E.T. 1994. Variety evaluation for farmer adoption: overview, setting objectives and requirements, p: $16-$ 22 In: Rasco, E.T and V.R, Vilma (Eds). Sweetpotato Variety Evaluation. SAPPRAD.

Saitama, A., A. Nugroho, E Widaryanto, 2017. Yield response of ten varieties of sweetpotato (Ipomoea batatas L.) cultivated on dryland in rainy season. Journal of Degraded and Mining Lands Management. 4(4): 919 - 926.

Kementrian Pertanian. Ubi jalar. 2016. Outlook ubi jalar komoditas pertanian sub sektor tanaman pangan. Pusat Data dan Sistem Informasi Pertanian.Kementrian pertanian.

Sasongko,L.A.2009. Perkembangan ubi jalar dan peluangpengembangannya untuk mendukung program percepatan diversifikasi konsumsi pangan di Jawa Tengah. Media agro. 5(1): $36-43$.

Tumwegamire, S., P.R. Rubaihayo, D.R. LaBonte, F.Diaz, R. Kapinga, R.O.M. Mwanga, and W.J.Gruneberg. 2011.
Journal Homepage:

http://ejournal.undwi.ac.id/index.php/jsds
Copyright (C) 2020 Dwijendra University. All right reserved. 
Journal of Sustainable Develpment Science

Vol. 2, No. 2, December 2020, pp. 60-68

e-ISSN: 2715-9140 | p-ISSN: 2722-919X

Genetic diversity in white and orangefleshed sweetpotato farmer varieties from east Africa evaluated by simple sequence repeat markers. Cropscience. 51: $1132-1142$.

Warhamni, D. Boer dan Muzuni. 2013. Keragaman morfologi ubi jalar
(Ipomoea batatas (L.) Lam.) asal kabupaten Muna. Jurnal Agroteknos 3(2): $121-126$.

Widowati,S. 2010. Diversifikasi konsumsi pangan berbasis ubi jalar. Pangan 20(1):49 - 61 . 